DOI: 10.15642/JIIS.2019.13.2.297-325

\title{
ACTORS AND NORMS IN AN ISLAMIC MARRIAGE A Study of Madura Community in Rural Eastern East Java
}

\author{
Muhammad Latif Fauzi | Leiden University - Netherlands \& IAIN Surakarta - Indonesia \\ muhlatiffauzi@gmail.com
}

\begin{abstract}
This article is concerned about everyday practice of marriage in religious community of Sumbersari, in Pasuruan, East Java. It analyses how actors and norms are involved to shape the practice. It also relates them to individual agencies of the couples. Materials of this article are based on my fieldwork that I did in early 2017. In this article, I suggest that the ideas of an ideal marital spouse are generally conceptualised in the set of localised notions of chastity (kesucian), good manner (apik), and good fortune (mompong) that necessarily culminate in the identity as santri (pious muslim). However, the implementation of these ideas are much dependent upon the roles of pelantar (traditional matchmaker) who mediates the communication of the two families concerned. In addition to pelantar, kyai (muslim cleric) is indeed important in the production of an Islam-based legal norm to control sexual morality that sometimes confronts against the state legal norm. Increasing participation in formal education and the rise of women's mobility have challenged this pattern. Girls have an autonomy to choose her preferred partner. Mutual love becomes more important, although the decision of marriage timing sometimes still belongs to the parents' authority.
\end{abstract}

Keywords: Norms, Islamic marriage, Madura community

\section{Introduction}

In Muslim societies, marriage is a contract of exchange regulated by a code of law rooted in religious precepts. In social practice it is imbued with the variety of local ideas and determined by diverse 
actors. ${ }^{1}$ In this article, I seek to explain how different actors in a religious community shape the practice of marriage. It seeks to answer a range of questions as follow. What factors or values are determinant? In what ways do individuals negotiate their agency with these norms? In addition to the couples, who are other actors involved? What values do these actors refer to and what are their orientation? In what ways does their involvement impact the ways women should behave? What changes have taken place?

Materials of this article result from my fieldwork in Sumbersari (pseudo name), a rural, religious sub-district in eastern East Java. Sumbersari society generally looks homogenous that can be identified with its strong attachment to a certain form of Islam that is referred to as "traditional Islam"2 or as "santri culture". ${ }^{3}$ However, despite its homogeneity in terms of Islamic orientation and practices, contemporary Sumbersari presents its internal heterogeneity in terms of marriage practice. For this reason, this article offers some narratives illuminating the complicated relationship between norms, agency of the actors involved and social structure as well as exposes recent changes.

Below I start with an overview of the intermixture of Islamic and cultural norms in Sumbersari. As an illustration, I present a brief sketch of how a young man deals with localised norms and social actors that impact social process prior to his marriage, i.e. finding a marital spouse. His experience leads me to an overview of a broader

1 Kecia Ali, "Marriage in Classical Islamic Jurisprudence: A Survey of Doctrines," Asifa Quraishi and Frank E. Vogel (eds), Islamic Marriage Contract: Case Studies in Islamic Family Law (Cambridge, MA: Harvard Law School, Islamic Legal Studies Program, 2008), pp. 11-45; Dawoud Sudqi el- Alami, The Marriage Contract in Islamic Law in the Shari ah and Personal Status Laws of Egypt and Morocco (London: Graham \& Trotman, 1992).

2 Zamakhsyari Dhofier, The Pesantren Tradition: The Role of the Kyai in the Maintenance of Traditional Islam in Java (Tempe: Arizona State University, 1999); M. Bambang Pranowo, "Pesantren, Traditional Islam in Contemporary Rural Java: The Case of the Tegal Rejo Pesantren," M.C. Ricklefs (ed.), Islam in the Indonesian Social Context (Clayton: Monash University Centre of Southeast Asian Studies, 1991), pp. 39-56; Mun'im Sirry, “The Public Expression of Traditional Islam: The Pesantren and Civil Society in PostSuharto Indonesia," The Muslim World 100, no. 1 (2010): pp. 60-77.

3 Zamakhsyari Dhofier, "Kinship and Marriage among the Javanese Kyai," Indonesia 29 (1980): pp. 47-58; Yanwar Pribadi, "Religious Networks in Madura: Pesantren, Nahdlatul Ulama, and Kiai as the Core of Santri Culture," Al-Jami'ab: Journal of Islamic Studies 51, no. 1 (2013): pp. 1-32. 
social life in Sumbersari. Here I identify two elements: the centrality of informal Islamic education compared to other institutions and economic life. The next section seeks to demonstrate the ways values of an ideal marital spouse are determined by the complicated relationship between social actors. Last section concludes.

\section{Presenting Munir-Ulfa: a Glimpse about Sexual Morality}

Munir was a 29-year-old married man when I met him in early 2017. Wearing sarong and the non-original jersey of an Englandfootball-club, he welcomed me to get in the house. The house is not his own, but belongs to his parents-in-law. Although changes are inescapable, there is still a tendency of local custom, that after marriage a husband lives in the bride's house. I was introduced to his family by my female local contact who was the classmate of Munir's wife when they were studying in the same pesantren (traditional boarding school) during the periods of 2006-2012. By visiting them, I initially expected to have an initial picture of the allegedly-popular practice of nikah sirri (unregistered marriage) in their surroundings. Interestingly, he tried to convince me that such a practice starts decreasing, although he mentioned some of his female neighbours whose (re)marriages had been concluded with no official registration. Even a few of their husbands are not always together with them on daily basis. He and I suddenly moved to a very personal talk about his life trajectories until he got into a marriage.

Munir graduated from a local Islamic junior high school (madrasah thanawiyah) in 2002. He did not study in a pesantren, but since in Islamic primary school (madrasah ibtidaiyah), he spent almost all the afternoon learning Islam in madrasah diniyah (informal religious school). Munir was taught with varied subjects about Islam, ranging from aqidab (theology), fiqh (Islamic jurisprudence), akblak (ethics) to Arabic grammar (nabwu). He is fairly familiar with classical figh doctrine as written in Islamic jurisprudence treatises (kitab kuning). ${ }^{4}$ After graduating Islamic junior high school, Munir decided not to continue his study, irrespective of the parent's supports, for a number of reasons. Among others was that he failed to make sense of what a higher formal education could contribute to his life. Acquiring a

4 Martin van Bruinessen, "Kitab Kuning: Books in Arabic Script Used in the Pesantren Milieu, Comments on a New Collection in the KITLV Library," Bijdragen Tot de Taal-, Land- en Volkenkunde 146, no. 2 (1990): p. 227. 
thorough understanding of Islamic matters appears to be more important for him. Munir further explained:

"Those who study at a senior high school usually expect to work in factories. I do not like this idea. You have to follow their strict rules, especially the working hours. It takes your freedom. What if one of your family gets sick, then you have to accompany him/her to hospital. You have to send a letter to ask permission. That is too rigid. Even my younger brother who just received a letter of acceptance from the factory decided not to go. He preferred to run a street stall."

For the period of 3 years, Munir was hired to be a substitute teacher (guru bantu) of a madrasah ibtidaiyah, where he studied, until 2005. Some other teenagers at his age do not stay at home. They rather live in big cities temporarily to have better jobs. After the holy month of Ramadhan 2006, Munir chose to follow his uncle heading to Jakarta, the capital city. Not so long in Jakarta working as a construction labour, he moved to Subang (West Java), working as waiter in a petty restaurant (warung) owned by a gentleman from Malang, East Java. He then moved to other cities in East Java, first Jember and later Surabaya. When he was in Surabaya, he was happy as he managed to visit his parents in his home village every fortnightly. However, in the mid2010 he decided to quit his job, because he needed to give a more intensive care of his father who was becoming older and weaker.

In the meantime, his father was worried about the future of his son's family life. At 23 years, Munir did not marry yet. Villagers generally consider a bachelor at this age, moreover when he could support his family, already mature to marry. ${ }^{5}$ Kholil, their neighbour, happened to hear about this situation, and offered him help to seek a suitable wife. He was thinking of his close relative, in the village where he originally came, who had a daughter maiden called Ulfa. Ulfa was at that time 15 years old, studying in a renowned pesantren in a suburb of Pasuruan. Munir and his parents agreed with Kholil's offer. Subsequently, Kholil came to see Ulfa's parents conveying a message that a male guy would visit them with a proposal asking their daughter to be his wife. Kholil played roles seemingly as a marriage broker, locally referred to pangada or pelantar. A pelantar is commonly perceived

5 Hildred Geertz, The Javanese Family: A Study of Kinship and Socialization (New York: The Free Press of Glencoe, 1961), p. 56. 
as taking an honourable mission because it mediates the communications between the two families concerned. ${ }^{6}$ This all social process is what local people refer to as ngen-angen (spread the words, literally winds).

Ulfa was the only daughter in the family. As the parent of a 15-year girl, Ulfa's parents found it delighted to receive such a proposal. Munir told me that Kholil might have been very convincing in promoting him before Ulfa's parents. Neither Ulfa nor Munir knew one another before. Shortly, Ulfa's parent was eager to have Munir's visit. This visit stage, called namu in Javanese, signifies a kind of preliminary negotiation. ${ }^{7}$ Culturally speaking, the parent's agreement of the man's visit implies their approval of taking their daughter as a wife. Following the approval from Ulfa's parents, accompanied by the pelantar, Munir visited her house. In traditional Javanese, it is called nontoni (viewing). ${ }^{8}$ The purpose of the visit is to grant a chance of both the prospective husband and the girl to see each other. In this nontoni stage, Ulfa did not sit with them in the meeting. Instead, she was asked to serve a cup of coffee to the guests, bringing it from the kitchen to the front room. It was in this very short encounter that both of them met and looked at one another. Munir was finally convinced to marry Ulfa. Religious considerations, particularly the idea of chastity (kesucian) of the girl, ${ }^{9}$ served to be the most fundamental explanation behind his decision. Ulfa was studying in pesantren that Kholil, and local people in general, assumed proper to secure their sexual morality. Ulfa and Munir then moved to next stage of engagement (nekeet).

The choice of Ulfa's prospective husband was made by his parents. Ulfa definitely believed that her family was able to decide on the value of this potential spouse for her so as she and her spouse might have a blessed life together. The marriage proposal was accepted, yet the

6 Anke Niehof, Women and Fertility in Madura (Indonesia) (Leiden: Instituut voor Culturele Antropologie en Sociologie der Niet-Westerse Volken, 1985), p. 115.

7 Geertz, The Javanese Family: A Study of Kinship and Socialization, p. 62.

8 Nancy J. Smith-Hefner, "The New Muslim Romance: Changing Patterns of Courtship and Marriage Among Educated Javanese Youth," Journal of Southeast Asian Studies 36, no. 3 (2005): p. 446.

9 Rural middle-class women in numerous parts of the world also have the tendency to accept patriarchal norms of honor and purity. See Santi Rozario, "Islamic Piety against the Family: From 'traditional' to 'Pure' Islam," Contemporary Islam 5, no. 3 (2011): pp. 285-308; Smith-Hefner, "The New Muslim Romance: Changing Patterns of Courtship and Marriage Among Educated Javanese Youth," p. 453. 
marriage ceremony was suspended until she completed her study. It is quite often that the parents directly marry their daughter off particularly when there is a big age gap between the bride and the groom. After the initial introduction, the prospective groom and bride generally have a chance to meet in private, under supervision. This was not applicable to Ulfa and Munir, because Ulfa returned back to pesantren. They did not exactly have a period of courtship with a series of private meetings, but with the presence of Ulfa's parents. During the period prior to the wedding, Munir was occasionally invited by her parents to go together with them visiting and delivering money (ngirim, Javanese) for Ulfa's education in the pesantren. There, he got the chance to meet his future wife. The locals anecdotally call the man's participation ngredit (paying off a lease). A future son-in-law needs to get involved in such a process to build his reputation as a good person before the potential parents-in-law and to socialise with their extended families.

Munir's experience suggests the central position of pesantren in shaping women's sexuality. It appears that pesantren education for a girl is important since it symbolises chastity. Meanwhile, Islamic norms on marriage have been an inseparable part of people's daily life and, thus, embodied into customary system. The division between the two has somehow blurred. Like in Javanese society, referring to early scholarly works on cultural norms (adat), it is difficult to identify which exclusively belongs to Islam and which derives from the pre-existing tradition prior to the coming of Islam.

Clifford Geertz, referring to Mohamed Koesnoe, stressed the notion of propriety when it comes the discussion about adat. He stated: "adat is constructed as "the form of life of the Indonesian people as founded in their sense of propriety". ${ }^{10}$ Therefore, Bowen has underlined that the term "law" cannot epitomise complicated norms surrounding marriage and other matrimonial matters in Indonesia. In rural settings, legal matters raise relationships with the older people, religious commitments and a sense of propriety. ${ }^{11}$ Because the

\footnotetext{
10 Clifford Geertz, "Local Knowledge: Fact and Law in Comparative Perspective," in Local Knowledge: Further Essays in Interpretive Anthropology (New York: Basic Books, 1983), p. 210.

11 John R. Bowen, Islam, Law, and Equality in Indonesia: An Anthropology of Public Reasoning (Cambridge: Cambridge University Press, 2003), p. 18.
} 
majority of the Sumbersari people profess Islam in a traditional way, their everyday life is impossibly separable from religious doctrines.

\section{Pelantar and Cultural Norms}

This section more elucidates the roles of pelantar and the influence of various local norms in social process prior to marriage. For this interest, I present the following Kulsum's marriage narrative to advance our understanding of how these factors work in practice.

This is the marital experience of Kulsum. When I met Kulsum in early 2007, she was 31 years and is married to the second husband. Her first marriage was concluded in 2001, a couple of months after she graduated from an Islamic junior high school. Raised in a religious family where the father was among respected religious leaders, she claimed to be the only girl in the village who went to a formal school at the time. However, she failed to continue to a higher level and was eventually married off. She told me the following:

"My father insisted me to keep studying. I was taken by him to hand in a registration form to a Islamic senior high school (madrasah Aliyah) in Sumbersari. My older sister nonetheless said binek noapah asekola, monduk beib rapab (as a woman there is no need for going to school, learning in pesantren is enough). Unfortunately, not long after, our beloved father got a fatal injury in an accident that led to his death. It was a destiny that changed my life dramatically."

After a while, Kulsum was married to a man from the same village. The family's decision to marry her was undoubtedly an outcome subsequent to the father's death. No one in the household could substitute his main roles to provide financial supports for her education. Kulsum had no options available as she expressed the notion of neser reng tuah (feeling pity for the parents). She did not declare verbally whether she gave her consent and agreed with the marriage arrangement. The only thing she could do is expressing silence (Javanese, manut). Silence here is the keyword. In the light of certain Shafici jurists, the silence of an unmarried woman can be deemed as her consent. ${ }^{12}$

12 Muhammad ibn Ismail al-San'ani, Subul al-Salam, vol. 3 (Riyadh: Maktabah Nazar Mustafa al-Baz, 1995), p. 132. 
Kulsum had reached the age of puberty when she was married. By the means of marriage, Kulsum was considered a legal adult and, therefore, competent in managing marital life. It is the marriage that shapes her maturity. Hildred Geertz has remarked that marriage was an important passage that marked the transition from social puberty to maturity, ${ }^{13}$ a cycle of rite of passages if we refer to Van Gennep's framework. ${ }^{14}$ Maturity here denotes the stage where women are considered capable of managing household affairs. The latter is congruent with the notion of rushd (legal capacity or financial competency) in the classical figh doctrine. There is no exact demarcation line which determines the age of rushd of a woman. It however includes the reliance on the consideration of the wali (legal guardian). Verification can be based on individual's religious piety as well. Some classical jurists, the Mālikĩ in particular, place marriage as an essential requirement for a woman to have financial competence. ${ }^{15}$

In fact, Kulsum started a family with very little knowledge about sexual relations and household management. Islamic marriage is a contract of exchange that involves a set of rights and obligations for each party. Kulsum had the obligation of submission to the husband, because she was sought to have the rights to maintenance. Under the umbrella of a marriage solemnization, she shifted to come under her husband protection. After marriage, Kulsum asked her husband and family to remain close to her mother. She and her husband then lived in a house next to her natal family's house. The marriage unfortunately survived less than two years. She was not lucky as she claimed that the husband was rude and disrespectful. When she encountered a problem with the husband, soon she complained about this to her mother. Moreover, she got the confirmation of mak kerreng lakennab be'en jeh

13 Geertz, The Javanese Family: A Study of Kinship and Socialization.

14 Van Gennep classified ritual ceremonial patterns which mark an individual's transitions in his/her lives, rites of passage. The concept of "liminality" was introduced to indicate the time where people are on the doorway of entering a new phase in their life. Rites of passage include rites of separation, transition rites, and rites of incorporation. Marriage is part of rites of incorporation, while rites of separation are apparent in funeral ceremonies. Meanwhile, transition rites take the forms of betrothal and pregnancy. Arnold van Gennep, The Rites of Passage (London: Routledge \& Kegan Paul, 1960), p. 11.

15 Nayel Badareen, "Identity and Authority: Changes in the Process of Debates over the Islamic Marriage Contract among Contemporary Muslim-Arab Intellectuals” (Ph.D Dissertation. The University of Arizona, 2014), p. 58. 
(what a rude man your husband is) from her older sister. Kulsum was suggested to ask for a divorce from the husband. The husband then granted talak (pronouncement of repudiation), witnessed by a religious leader and her family. Despite the social stigma as a divorcee, Kulsum decided not to remarry. She rather continued to study in an equivalent senior high school (kejar paket $C$ ) and participated in social activities. Ten years after, in 2012, she decided to obtain an official legal validation of divorce after proposing a divorce petition (gugat cerai, Indonesian) to local religious court.

In a society like southern Sumbersari whose cultures share cultural and historical relationship with that in Madura, marriage is generally placed in the prerogative of families. Obedience to parents, particularly the father, is presented at the highest position in the hierarchy of respects for important social figures. This cultural notion is represented in a well-known Madurese dictum of obedience bhuppa' bhabbu' ghuru rato (father, mother, teacher, and king respectively). However, although the power over the household and land belongs to the male authority, marriage pattern tends to be matrilocal in nature. A husband moves to live with his wife's family after marriage, especially when the husband does not own a house himself. Within this custom, it is relatively easier for a woman to get protection and support from her natal family.

Both aforementioned cases demonstrate the practice of arranged marriage. It is a form of marital union where the parents, usually the fathers, choose appropriate spouses for their daughters or sons. It happens more often when the female spouse is young and the male is much older. Sumbersari people refer to this marriage arrangement as ajuddhuagi (arranged marriage). This local term nevertheless implies not only the decision on the choice of spouses, but also the decision of the marriage timing. Furthermore, the arrangement also applies to the two types of marriage, be it registered or unregistered, although registration is dependent upon multiple factors, such as whether or not the girl's age is eligible for a registered marriage or the existence of a legal document in the case of remarriage.

Nilan argues that marriage among middle-class families is attributed to religiosity and family background, but the former appears to be less prioritised. ${ }^{16}$ Furthermore, in different Asian contexts, the

16 Pam Nilan, "Youth Transitions to Urban, Middle-Class Marriage in Indonesia: Faith, Family and Finances," Journal of Youth Studies 11, no. 1 (2008): pp. 65-82. 
practice of arranged marriage is also justified by the ideologies of family honour and shame. ${ }^{17}$ Local people usually opt for arranged marriage as a manifestation of control and preserving social honour. Like Ibu Fatimah, parents from a certain respected class in Sumbersari are concerned to ensure that their daughter marries to an appropriate man. For this reason, girls' mobility is under a tight control. The concept of a prospective husband is based primarily on religious orientation and moral capital. There is a feeling of fear of stolen by others (takok ekalak oreng, Madurese), when a kiai (man with good religious knowledge) comes to ask their daughter. Wealth and social standing are not as important as the notion of good manner.

Despite a general claim saying that no marriage is possible without material capital, the Javanese phrase bibit, bobot, bebet (family lineage, personal quality, wealth) is a concept that emphasises the notion of 'good manner' (apik) in everyday practice. In the East Javanese context, Beatty revealed that understanding social sentiments leads us to recognise the roles of emotions beyond the family and the shaping of a community. The emotions such as shame, reluctance, and respect fabricate societal relationships in which the concept of apik, in opposition to 'bad' (elek), plays a constructive part. ${ }^{18}$ The most visible embodiment of the notion of apik in everyday practice of marriage lies in the selection of a marital spouse. An emphasis is given more to the degree of religious aspects and moral character (oreng bhagus, Madurese: a good man). The identity as santri (a graduate of pesantren, in this context) will be highly preferable. When someone offers parents of a girl a young man having this qualification, parents would scarcely decline the proposal.

Furthermore, my materials from fieldwork suggest that financial resources of the groom frequently come to be the very last consideration. However, we cannot ignore that the social background of the prospective husband is something that parents give attention to. Therefore, despite the concept of apik, economic motivation for a woman and her family sometimes appears to explain why she get

17 Santi Rozario, "Islamic Marriage: A Haven in an Uncertain World," Culture and Religion 13, (2015): pp. 159-175.

18 Andrew Beatty, "Feeling Your Way in Java: An Essay on Society and Emotion," Ethnos: Journal of Anthropology 70, 1 (2005): pp. 53-78. 
married. The idea is that the husband plays roles as the breadwinner and the wife acts as a money manager in the household. ${ }^{19}$

The concept of apik in marriage also articulates in sexuality. It has to do with the notion of woman's chastity. Chastity is culturally deemed as an essential symbol of the family honour. Local people engages a cultural term, referred to as praban (virgin girl), ${ }^{20}$ that specifies an idealised prospective wife. It is imposed through a social mechanism which prevented women from publicly revealing interactions with unrelated members of the opposite sex. Those who breach this mechanism were labelled as not knowing orders ( $t a^{\prime}$ tao thenka, Madurese). Likewise, while choosing Ulfa, Munir confessed that Ulfa's chastity (kesucian) came to be the main consideration. This also applied to Kulsum. Men are generally stimulated with a principle that puts religious morality of the women as the top priority. ${ }^{21}$

Moreover, marriage is not as simple as an Islam-based-contract which makes sexual intercourse between the bride and the groom licit. ${ }^{22}$ A wide range of social contexts coexists, instead. Hallaq denotes the position of Islamic marriage as the cornerstone of communal harmony. ${ }^{23}$ It is worth noting that numerous marriages in my research site involved people of close relatives. This marriage is considered to be a strategy to consolidate familial relationship and land ownership. Referred to as mapolong tolang (collecting the scattered bones), ${ }^{24}$ such a marriage is intended to preserve the property of a family from outsiders (oreng lowar). ${ }^{25}$

19 Nurul Ilmi Idrus, Gender Relations in an Indonesian Society: Bugis Practices of Sexuality and Marriage (Leiden: Brill, 2016), p. 82.

20 Niehof, Women and Fertility in Madura (Indonesia), p. 107.

21 A Prophet tradition relevant to this issue is for instance written in Islamic books, such as Bulügh al- maräm: "Tunkah al-mar'atu li'arba ìn, lidinihä, linasabihä, lijamälihä, wa limälibä." This means that "marry a woman for the intensity of her religious devotion, kin reputation, beauty, and wealth. Aḥmad b. 'Alī Ibn Hajar al- 'Asqalāní, Bulügh AlMarām Min Adillat Al-Ahkeam (Riyadh: Maktaba al-Rushd, 2005), p. 350.

22 Ali, "Marriage in Classical Islamic Jurisprudence: A Survey of Doctrines," p. 12.

23 Wael B. Hallaq, Shari'a: Theory, Practice, Transformations (Cambridge: Cambridge University Press, 2009), p. 271.

24 Iik Arifin Mansurnoor, Islam in an Indonesian World: Ulama of Madura (Yogyakarta: Gadjah Mada University Press, 1990), 84.

25 A. Latief Wiyata, Carok: Konflike Kekerasan Dan Harga Diri Orang Madura (Yogyakarta: LKiS, 2002), p. 58. 
In respect to the marriage ages, the locals consider the age of 19 for women is too late for marriage. Without a doubt, the significance of marriage for women relates to the concepts of marriageability and "saleability." An adult woman who is unmarried is socially perceived as unsaleable maiden or old girl (perawan tua). Meanwhile, men do not have this saleability stereotype when they are unwed. Instead, people surrounding him will make fun of him as not brave (tak bengal), banci (effeminate), or other things connected to sexual potency. ${ }^{26}$

Moreover, Kulsum's marriage, and her divorce, underlines the local notion of juddhu (jodoh, Indonesian; divine destiny). Meanwhile, in terms of marital spouse juddhu has to do with the principle of mompong (good fortune). Parents, not necessarily father, are more committed to the concept of mompong bedheh se mentah (having a good fortune that a male is proposing a marriage). The application of the principle having a good fortune is claimed to have justification from Islamic ideas that circulate among them. Kyai Hidayat, a respected ulama' in the southern Sumbersari, argued that a woman should not accept anyone but a man who is religiously committed and of good character. He referred to a hadith narrated by al-Tirmidhi (d. 892) stating that if there comes to a father to marry (off her daughter) one who has religious commitment and good characters he is pleased, then he should marry her to the man. If he does not do that, there will be tribulation (fitnah) in the land and widespread corruption. ${ }^{27}$

In addition to mompong and apik, pelantar clearly appears to be an important actor that form marriage practice. As that in the case of Munir, proposals for marriage are commonly conveyed to the girl's parents through the means of pelantar (intermediary), sometimes referred to as pengarep. Pelantar is a person, usually a family member or a close neighbour, who functions as a marriage matchmaker. Although matchmaking is undertaken voluntarily, a pelantar is sought to have the responsibility for finding a suitable wife for the young man. The pelantar will do his/her best to appeal her parents. Whatever the answer will be like, either acceptance or rejection, the pelantar will communicate it to the man or his parents. Some people still believe that rejecting the first marriage proposal for their daughter is socially

26 Idrus, Gender Relations in an Indonesian Society: Bugis Practices of Sexuality and Marriage, p. 82.

27 Abī '̄isāa al- Tirmidhī, Jāmi 'Al-Tirmidhì (Riyadh: Bayt al-Afkār al-Dawliyya, 1999), p. 192. 
inappropriate. There is a local belief that it may lead to sangkal (misfortune), a proposed daughter will become a spinster. Based on Niehof's research findings on Madura island in the 1980s, the concept of sangkal articulates the concern for a girl's marriage prospects that contributes significantly to the perpetuating of the custom of early marriage. ${ }^{28}$

The roles of pelantar are essential in many ways, particularly when women's mobility and social interaction between different genders are controlled strictly. Gus Raibin, my key informant, indicated that upon receiving a yes-answer from the girls' parents, the young man's family has the confidence to make a betrothal for engagement (peneket). The presence of pelantar may prevent the risk of making the male's parent shame, once the proposal is unaccepted. Here, it underscores that the local notion of shame is embodied not only in controlling girl's sexuality but also in maintaining family's dignity. In the case of remarriage, the function of pelantar is not absent. When a divorcee or a widow is about to finish her waiting period ('idda), a pelantar usually comes to her to deliver a marriage proposal.

Kulsum's post marriage could not escape from the interference of pelantar. Despite no legalisation from the state over her divorce, the community recognise Kulsum as a divorcee. For this reason, she was often requested to welcome male guests (tamu) asking her to be a wife. In many occasions, it was even her own brother-in-law who took nobody to her house. It was hard for Kulsum to accept this reality, although she could understand why close relatives commonly did so. What was in her brother's mind was to help Kulsum improve her life. Feeling uncomfortable, she tried to negotiate her stance with this given local tradition. An agreed compromise between her and her brother was finally drawn: la kadung dennak jek dus nodusin, temmonen beib lab tak usa terrosagi (the guest already shows up, just greet him, no need to take it seriously).

\section{Seeking for a 'Middle Ground': Roles of Kyai}

This section is devoted to elucidates the roles of religious leaders (kyai) who in Java perfors not only in religious authority but also social cultural influence in managing the problems of marriage and sexuality. The case that I analyse here stems from the experience of Kyai Karim,

28 Niehof, Women and Fertility in Madura (Indonesia), p. 109. 
a prominent kyai in Sumbersari, dealing with a polygamous marriage. This case is interesting considering the socio-political position of him. $\mathrm{He}$ is not just a common religious leader who runs a pesantren. More than that, he is among top leaders in both social and semigovernmental Islamic organisations. To mention, he is the head of the sub-district level of the Indonesian Council of Ulama (Mejelis Ulama Indonesia) and is one of the advisory chairmen of the regional article of Nahdlatul Ulama'. At these positions, his understanding of how different legal systems operate is unquestionable. Moreover, the locals recognise him as a religious leader whose understanding of Islam is not fanatical (tidak kolot) and open (terbuka) to the modernising world. However, in this case, we will notice how he maintained his authority as ulama, that is, as he claimed, responsible for controlling morality, and in return challenged the state law. Fealy and Bush have remarked that ulama still find themselves subject to competing pressures from the society and the state. ${ }^{29}$ What follows is the narrative.

\section{Narrating Polygamy}

A few years ago a couple of a man and a woman came to his pesantren. The man confessed that he has been for a few years in a love relationship (pacaran) with the woman whose age at the time was around 25 years. He even claimed to have rented her a house so he could easily make intimate interaction just like (seperti layaknya) a husband and a wife. Kyai Karim argued that the word "seperti layaknya" expressed by the man was a pseudo term to refer to an extramarital sex, locally recognised as kumpul kebo (sex out of wedlock). Definitely, Kyai Karim urged them to conclude a marriage ceremony in order to legitimise (menghalalkan) their relationship. However, the problem was in fact not as simple as he expected. The man was a civil servant and had been married to another wife. Important to note that a male civil servant in Indonesia is prohibited to conduct polygamy unless with a permission from his supervising official. ${ }^{30}$ Kyai Karim was in a dilemma. As a religious leader, he was bound to a doctrine in classical

29 Greg Fealy and Robin Bush, "The Political Decline of Traditional Ulama in Indonesia," Asian Journal of Social Science 42, 5 (2014): pp. 536-560.

30 This prohibition is ruled in the government regulation no. 45/1990 jo. the government regulation no. 10/1983 on the permission for marriage and divorce of civil servant. See Kate O'Shaughnessy, Gender, State and Social Power in Contemporary Indonesia: Divorce and Marriage Law (London and New York: Routledge, 2009), p. 34. 
Islamic law that fear of extramarital sex makes it obligatory for a man to marry.

Shortly, he solemnised their marriage without official registration as he believed the only way out to save the couple's religious morality from sinful kumpul kebo according to Islam. For the man, it was a polygamous marriage. After the conclusion of the marriage ceremony, Kyai Karim asked the couples to sign a letter declaring that they have been tied in a religious marriage. As far as my observation in the field, as if the letter functions as a marriage certificate. The letter mentions the names of the couples, the witness, and the religious leader who solemnizes the marriage. Kyai Karim suggested the woman always be patient for her position as a second wife in an unofficial polygamy. However, the man found it hard to maintain good relations with her, especially when she demanded legal certainty over her status as a wife. As the man failed to meet her wishes, she decided to report this informal marital union to the man's supervisor, bringing the signed informal-marriage letter. Soon this polygamous marriage became a public rumour among his colleagues.

A prominent official from the man's office accordingly went to meet Kyai Karim in order to make sure whether the woman's complaint was with basis. If so, the man was susceptible to get legal sanctions due to non-procedural polygamy. The official complained Kyai Karim about his decision of marrying them with an accusation of "selling" marriage ceremony. Kyai Karim felt way offended and, in return, blamed the official for being incapable of controlling the staff's morality. He then challenged the official with a set of questions as shown in the following conversation.

\begin{tabular}{|c|c|c|}
\hline Kyai Karim & & Excuse me, what is your current structural position? \\
\hline Official & & Echelon 3 \\
\hline Kyai Karim & & $\begin{array}{l}\text { If you are on an official travel, then you meet with a } \\
\text { woman whom you want to date. What will you do? }\end{array}$ \\
\hline Official & & Yes, that is typical to man. \\
\hline Kyai Karim & & $\begin{array}{l}\text { Well, you finally mention that word "typical to man". Do } \\
\text { you wish to 'buy' or marry? } \\
\text { I actually cannot accept polygamy because it is difficult to } \\
\text { give justice to wives. But, if you do not marry, you will } \\
\text { commit an extramarital sex. Please do not complicate the } \\
\text { problem, but make the best solution. }\end{array}$ \\
\hline Official & & Yes, Kyai, (this is tricky) so how?) \\
\hline
\end{tabular}


Muhammad Latif Fauzi

Kyai Karim : This condition obliges you to return to religious rules. You are supposed adhered not only to the state regulation, but also religious teaching.

The above conversation shows that Kyai Karim used Sharia as the solution of kumpul kebo where he framed as a consequence of the obstruction generated by a state regulation. In this situation, he argued Sharia had to do something to first secure one's religious life. However, he then underlined that religion should not easily be used as a broom sweeping sins. In fact, while a couple is already fallen (terperosok) into grave sin and the state law has an administration-based legal restriction, religious authorities cannot just leave them in sinful acts endlessly. He stated:

"Polygamy is very casuistic. From common perspectives, no wife can accept her husband takes another wife. I have a daughter. I will never accept if her husband does consecutive marriages. But, in the case where a man finds it morally obliged (terpaksa) to perform polygamy, he has to do it although it is not easily accepted by the society. God has indicated that polygamy is difficult. It only applies to certain conditions."

\section{Legal Reasoning: Seeking 'Middle Ground'}

Existing literatures have enhanced our insight into the compound relationship between social norms and legal practice ${ }^{31}$ where Sharia continues to be an independent normative system. Cammack et all have argued that control over marriage practice takes place in a contested arena where different social actors seek to exercise their power. ${ }^{32}$ Meanwhile, contemporary public debates about Islam and social changes in Indonesia indicate that Sharia-based interpretations increasingly challenge the legal concept of marriage introduced by the state. In regards to the law making process, Cammack argues that despite the failure to impose the obligatory enforcement of Sharia for the adherents of Islam, Muslim successfully held out traditional Islamic

31 Bowen, Islam, Law, and Equality in Indonesia: An Anthropology of Public Reasoning, 8; Sally Engle Merry, "Law, Culture, and Cultural Appropriation," Yale Journal of Law \& the Humanities 10, 2 (1998): pp. 575-603.

32 Mark Cammack, Lawrence A. Young, and Tim B. Heaton, "Legislating Social Change in an Islamic Society: Indonesia's Marriage Law," The American Journal of Comparative Law 44, no. 1 (1996): pp. 45-74. 
norms against the preceding legislative efforts to change the substance of Islamic marriage law. ${ }^{33}$

What has happened in contemporary social practice? Based on the social relations in a West Java's regency, Stijn van Huis suggests that the modernisation of law on marital affairs has negatively affected the authority of ulamas. They have to create a completing legal order and to challenge the authority of Islamic court, in terms of judicial divorce, in order to preserve their authority. ${ }^{34}$ Still in West Javanese context, Grijns and Horii found dilemmas and compromises at the societal level that epitomise contending norms on marriage and sexuality. They emphasise the influence of conservative interpretation of Islam in controlling morality that leads to the continuing practice of child marriage. 35 Platt, in the localised context of religious Lombok, convinces us that the state law on marriage has been unsuccessful to take over the so-called community-based law in the form of localised Islam and adat. In other words, social acceptance still has priority over the state-based legitimacy. Respective legal processes in Islamic court do not always bear significant outcomes for a woman as she is already caught in different legal systems. ${ }^{36}$

From the above case, it can be said that Kyai Karim's reasoning about Islamic marriage culminates in the notion of "guarding Sharia". This entails at least two aspects: legalising (sexual) relations and avoiding harms (sinful acts). However, the way Kyai Karim copes with the above polygamy case deserves close attention, especially from the side of legal reasoning he used. In the interviews, Kyai Karim stated: "Saya mengambil garis tengah pada kasus yang terjadi. Kalau mau disiplin ya pakai Syafi' (I took a middle ground to resolve the case. If you are strict in applying Islamic law, you are expected to follow the Shafici maddhab). Despite the supremacy of the Shafí 1 madhhab in the area, he clearly admitted that the Shafíi ${ }^{\top}$ way was not applicable to settle the

33 Mark Cammack, "Islamic Law in Indonesia's New Order," International and Comparative Law Quarterly 38, 1 (1989): pp. 53-73.

34 Stijn van Huis, “Islamic Courts and Women's Divorce Rights in Indonesia: The Cases of Cianjur and Bulukumba" (Ph.D Dissertation. Leiden University, 2015), p. 139.

35 Mies Grijns and Hoko Horii, "Child Marriage in a Village in West Java (Indonesia): Compromises between Legal Obligations and Religious Concerns," Asian Journal of Law and Society (2018): pp. 1-14.

36 Maria Platt, Marriage, Gender and Islam in Indonesia: Women Negotiating Informal Marriage, Divorce and Desire (Oxon and New York: Routledge, 2017), p. 36. 
problem. Therefore, he underscored the notion of "middle ground". By saying so, he emphasised that this was not an ordinary case, and thus demanded an alternative legal settlement.

What he meant by "middle ground" was moving from the Shäfi' 1 school to another madhhab. In this case, it was about wali (marriage guardian) for women. The fact was that the woman came before him with no one, but her beloved man. It was not clear whether the woman had already obtained the consent of the biological wali (Indonesian, wali nasab) before, which is required in Shafi' 1 maddhab. In an ordinary situation, wali nasab may delegate his rights to marriage guardianship to another person. This process is known as tawkil wali. Due to the impossibility of making this process, Kyai Karim had no choice than proceeding the marriage ceremony without the consent of the woman's wali, following the Hanafi school.

It is worth to note that there have been debates among classical Muslim jurists concerning wali and woman's legal capacity of marriage. For men, the age of puberty (buligh) $)^{37}$ signifies the change in the walis authority. After reaching puberty, men can conclude their own marriage contract and may not be coerced into marriage. For women, puberty signs their capacity to withstand sexual intercourse and determines the minimum legal age of marriage. According to certain Shafíi ${ }^{-}$opinions, permission must be sought from a single/virgin woman (bikr). Nevertheless, the Shaffic school employs virginity (being unmarried) as the ground of the wali to use his compel power (ijbar). This means that a wali, particularly the father, may coerce his female virgin wards (bikr) into marriage, irrespective of whether they are minor or adult. ${ }^{38}$ By contrast, the Hanafi jurists argue that an adult girl has the legal capacity to contract her marriage independently and without the consent of the wali.

\footnotetext{
37 The majority of Sunni jurists indicate the appearance of pubic hair for both girls and boys and the nocturnal emission for boys to be biological signs of puberty. In the absence of these signs, they consider certain ages: nine lunar years for girls and twelve lunar years for boys. Badareen, "Identity and Authority: Changes in the Process of Debates over the Islamic Marriage Contract among Contemporary Muslim-Arab Intellectuals," p. 53.

38 Muhammad Khalid Masud, "Gender Equality and the Doctrine of Wilāya," Ziba Mir-Hosseini et al. (eds), Gender and Equality in Muslim Family Law: Justice and Ethics in the Islamic Legal Tradition (London: I.B. Tauris, 2013), p. 130.
} 
Furthermore, notwithstanding different views on the aspects underpinning a marriage contract, three aspects are required to be present: the bride and the groom, offer and acceptance (ijab and qabui), and the pronouncement of the marriage contract (sigha). Muslim jurists disputed over other aspects, namely dower (mahr), witnesses (shubada), and the marriage guardian (wali). In the light of Shafíi and Maliki jurists, these all have to be present. Only the Hanafi jurists argue that a marriage without the consent of a wali may be valid. ${ }^{39}$ Regardless, behind the decision of taking "middle ground" by Karim Karim lies certain legal reasoning. His argument was constructed on the basis of a principle that "if there is a fear that the woman may fall into immorality (fasad $)$, the judge may marry her to a man of her social status (kufu)." 40 This principle is relied upon the hadith no. 1879, narrated by Aisha, from the collections of Ibn Majah saying "Any woman whose marriage is not arranged by her guardian, her marriage is invalid, her marriage is invalid, her marriage is invalid. If (the man) has had intercourse with her, then the mabr belongs to her in return for his intimacy with her. And if there is any dispute then the ruler is the guardian of the one who does not have a guardian". ${ }^{4}$

This 'illegal' polygamy case necessarily resonates with the notion of internal plurality of a law. Salim quoted Menski's concept of "a quadrangle of law" that has been essential for the further development of the triangle of law introduced by scholars earlier. ${ }^{42}$ An important point from his model is not only four elements of law (state, religion, society, and international), but what he terms "plurality of pluralities." It means that each of the elements of law has internal plurality too. This concept appears relevant if we refer to what Kyai Karim did. By

39 Susan A. Spectorsky, Women in Classical Islamic Law: A Survey of the Sources (Leiden/Boston: Brill, 2010).

40 Islamic jurists refer to the hadith no. 1879, narrated by Aisha, from the collections of Ibn Majah saying “Any woman whose marriage is not arranged by her guardian, her marriage is invalid, her marriage is invalid, her marriage is invalid. If (the man) has had intercourse with her, then the mahr belongs to her in return for his intimacy with her. And if there is any dispute then the ruler is the guardian of the one who does not have a guardian." Muḥammad ibn Yazīd Ibn Mājah, English Translation of Sunan Ibn Majah with Commentary, Vol. 3. (Riyadh: Darussalam, 2007), p. 78.

41 Ibid.

42 Arskal Salim, Contemporary Islamic Law in Indonesia: Shari'ah and Legal Pluralism (Edinburgh: Edinburgh University Press, 2015), pp. 25-26. 
saying "not only adhered to the state regulation, but also religious teaching", he tended to position the state law and Sharia in an oppositional pairing. Moreover, Kyai Karim settled the case by exploiting the internal plurality of legal opinions in Islamic jurisprudence. He made a creative legal reasoning in order to handle the case in accord with Islamic law. To deal with different legal practices, he was aware that strict reliance on a particular madhhab is not possible. Relevant to this respect, Bowen has argued that Islam needs an own reshaping in its response to the variety of contexts. In his opinion, a Muslim scholar has to be engaged in legal reasoning, thinking outside the madhhab, and the reinterpretation of Islamic norms, as well as the incorporation of adat into law. ${ }^{43}$

\section{Current Changes: Marriage to Legalise Sexual Relationship}

In this section, I present two case studies to demonstrate the fact that ideas and practices of marriage are not static. Changes are underway. On the basis of the individual experiences of newly-wed girls, Sumbersari society is witnessing diverse forms of the increase in women's individual autonomy. Thanks to the improved access to formal education and the widely-open job opportunities for highschool graduates, girls have a wider room to exercise their agency in choosing their partner. Social mobility comes to be driving factor of the changing outlooks of marriage and sexuality. Nevertheless, as shown in the first case, the fiqh-based conception of the authority of a marriage guardian still works to define appropriate girl's sexuality.

In February 2017, my local collaborator brought me to visit Aini's family. Aini, 21-year-wife, was married in September 2011. After graduating Islamic primary school (madrasah ibtidaiyab), Aini studied in a prominent pesantren in a sub-urban area. Although the majority of pesantren has established madrasah with a graded-class system, not all of them adopt state education system. She preferred this particular pesantren because it runs a madrasab that combines both religious and secular subjects, employing the state curricula. In this pesantren, she, unfortunately, could not enjoy living there and, therefore, survived only a couple of months. She returned home and was then sent to a local pesantren close to her village. This did not last very long as well. My collaborator said that Aini wished to study in an Islamic formal

43 John R. Bowen, Shari a, State, and Social Norms in France and Indonesia (ISIM Paper No. 3. Leiden: Institute for the Study of Islam in the Modern World, 2001). 
school, instead of in pesantren. Eventually she obtained the permission from her parents to continue at madrasah thanawiyah in the sub-district centre. Compared to other classmates, she was older and looked more mature. Her parents were not really happy with this situation, more or less because in that school Aini was open to interact not only with her female classmates but also male ones.

In the meantime, a young man, Ulum, fell in love with Aini. Ulum was 3 years older. He graduated the same school, yet at the time was in the second year of vocational high school (sekolah menengah kejuruan). Aini had the same feeling as Ulum. She said that they experienced pacaran (courtship), but never met in a private date (kencan). Shortly, Ulum proposed her to be a prospective wife, and promised to marry her only after she completed her school. Beyond Aini's expectations, Ulum's parents suddenly came to see her parents, proposing her to be Ulum's wife. Her parents were very surprised with the proposal although this is not unique to their tradition. Aini's parents happened to understand that their daughter already had a special relationship with her male counterpart. The parents were in dilemma. The fact that their children had been already emotionally attached became the main concerns. In addition, rejecting a marriage proposal is morally humiliating in the eyes of their society. There was a kind of fear that their children would interact too intimate and might possibly cause any forms of social dishonour. The father decided to accept the proposal and let his young daughter be engaged. A couple of months later she married and quit school because the school could not accept a married student.

Aini now spends her days at home as a housewife, raising a 3-year daughter. I talked to her, in Javanese with Madurese accent, about this episode of her life. In a lower voice with starry eyes, Aini exposed sadness of dropping out from secondary school. Nevertheless, this did not necessarily symbolise her displeasure. When I asked if she was happy with the marriage, she then smiled, signalling her excitement to marry a man of her own choice. She admitted that she was glad that pesantren taught her the values of ikblas (sincerity) and syukur (gratitude). Ulum and Aini were already acquainted with each other. Although the marriage ceremony went too early, Aini was happy to get married to the man of her choice.

Koentjaraningrat remarks that a certain aspect of santri religious system provides the individual with a basic feeling of security through 
the conclusion of an intensive personal relationship with God. ${ }^{44}$ This supposition still looks relevant to Aini. I asked her opinion on her marriage that was arranged by her parents and she responded as follows: "We had the feeling of closeness (dekat) for a couple of months. You may name it pacaran, but it was not as usual. We never went to a date. Pacaran is really prohibited, while kencan (dating) is anomaly and taboo." Again, Islamic marriage is not perceived merely as a contractual tie. For Muslim in Sumbersari or elsewhere, marriage serves more as an act of worship (ibadah) which, according to the Prophet's tradition, fulfils half of religion. It unites physical (lahir) and spiritual (batin) forces that leads a husband and a wife to commit their body and soul to one another for the sake of God.

In the case of Aini, it was none of importance for the parents to have an approval confirmation from her when the marriage proposal from Ulum's family was accepted. Aini, therefore, did not declare her agreement or rejection over the parent's decision. Even if she refused, considering the tradition of her society, the guardian father would use the rights to coerce her into marriage. The fathers, or other male guardians, have decisive roles in controlling their daughters' behaviour ${ }^{45}$ and in determining the validity of a marriage contract. ${ }^{46}$ Whatever, the 1974 Indonesian marriage Act requires the consent of both spouses. Both the bride and the groom have to sign a letter of consent (surat persetujuan mempelai or $\mathrm{N} 3$ form) to be submitted to the marriage registration office as part of obligatory documents to have marriage ceremony registered.

Despite the decision made by her father, Aini's marriage presents an ambivalence which necessarily suggests the evolution of sexual norms in a traditional community. Aini herself chose the spouse, but the father decided the marriage date. The younger generation in Sumbersari shows a greater tendency to choose their own husbands, but marriage date is not always of their decisions. During the last decade, in conjunction with the increasing access to, and the extended duration of, formal education, schools provide a room where young generation can meet prospect partners. Girls and boys are not

44 Koentjaraningrat, "Family and Religion in Indonesia," East Asian Cultural Studies 13, no. 1/4 (1974): p. 67.

45 Ann Black, Hossein Esmaeili, and Nadirsyah Hosen, Modern Perspectives on Islamic Law (Cheltenham: Edward Elgar Publishing, 2013), p. 129.

46 Masud, "Gender Equality and the Doctrine of Wilāya," p. 12. 
separated in school or classroom so that they manage to interact to each other regardless of different genders. As a consequence, youths, especially girls, are more open to the notion of mutual love (la padeh senneng). This mutual love has been instrumental in the shaping of local marriage behaviour, that sexuality of the young is no longer exclusively a familial affair.

Aini's mutual love seems to demonstrate reciprocal sexual relationships. However, her experience demonstrates something different. Woman's increasing autonomy in the choice of marriage spouse does not necessarily result in a more egalitarian view of gender relationship in family. When I asked about her understanding of gender relations in Islam and how it manifests in her marital life, she was of the view that a devout Muslim wife is ideally submitted to her husband's leadership and sexual advances. ${ }^{47}$ This outlook is much relevant to the conservative understanding of gender relations in Islam as disseminated in pesantren. Only a small number of pesantren has introduced a certain degree of gender equality. ${ }^{48}$

Concerning marital relationship, Aini and students in pesantren are familiar with Uqüd al-lujayn fí bayän huqūq al-zanjayn by al-Shaykh alNawawi al-Bantani (1813-1898 AD), an Arabic textbook dealing with gender relationship in family claimed to uphold the patriarchal ideas of gender relations. ${ }^{49}$ The book is not part of regular curricula, but is usually read during the month of Ramadan where they voluntarily come to hear. This textbook for ages has been shaping pesantren's understanding of gender relationship between husband and wife, in which husband is superior dominant to wife. There are four articles in the book, where the first two articles address the rights and obligations of wife and husband in a family. The first article concerns husband's obligations to his wife, namely giving good treatment, providing livelihood and dowry, as well as guiding her about rituals and wife's

47 Nina Hoel and Sa'diyya Shaikh, "Sex as Ibadah: Religion, Gender, and Subjectivity among South African Muslim Women," Journal of Feminist Studies in Religion 29, 1 (2013): pp. 69-91.

48 Bianca J. Smith and Mark Woodward, "Introduction, Decolonizing Islam and Muslim Feminism," Bianca J. Smith and Mark Woodward (eds), Gender and Power in Indonesian Islam: Leaders, Feminists, Sufis and Pesantren Selves (London and New York: Routledge, 2014), p. 10; Husein Muhammad, Fiqh Perempuan: Refleksi Kiai Atas Wacana Agama Dan Gender (Yogyakarta: LKiS, 2001).

49 Eka Srimulyani, Women from Traditional Islamic Educational Institutions in Indonesia: Negotiating Public Spaces (Amsterdam: Amsterdam University Press, 2012), p. 125. 
obedience to the husband. The second article is related to wife's obligations to husband which include good caring of him, submitting her body to him, staying at home while the husband is away, and covering shame (aurat). There have been attempts from pesantren circle to clarify these patriarchal interpretations, arguing that gender bias is of sociological construction, ${ }^{50}$ but apparently with mixed response.

Now, Aini stays at home, keeping up with the house and taking care of the children. Nevertheless, while the husband is working outside the home, she could still seize her free times in the morning to do economic activities which generate a relatively small money. She, so other neighbouring mothers, works decorating fabric (embroidery) as the materials for Islamic dresses. The money she gets is pretty enough to give pocket money for her children.

\section{Conclusion}

In this article, I have discussed the ways people in religious Sumbersari conclude their marriage. Despite the homogenous tradition of Islam in the area, the above narratives clearly indicate internal heterogeneity of the relationship between agency of the actors involved, cultural norms and social structure in the decision of whom, when, and how to marry. I suggest that in all classes, ideas of an ideal spouse have been closely related to the discourses circulating within traditional Islam with pesantren as the centre for knowledge production. These ideas include the values of chastity (kesucian), good manner (apik), and good fortune (mompong). The identity as santri epitomises these values. In regards to Munir's pre-marriage process, we see while pesantren has been an important enterprise that maintains the fiqh-based orientation of marriage, being a santri signifies purity and good morality of a girl.

Marriage practice in Sumbersari also shows that the implementation of the above ideas are much dependent upon the roles of pelantar (traditional marriage matchmaker). With a main role of mediating the communication of the two families concerned, pelantar are very important in families of religiously-respected class as well as families whose girls are trained in pesantren. Pelantar help to protect reputation of the family and social honour. Not only first marriage,

50 Masdar F. Mas'udi, "Perempuan Di Antara Lembaran Kitab Kuning," Lies Marcoes and Johan Hendrik Meuleman (eds), Wanita Islam Indonesia Dalam Kajian Tekstual Dan Kontekstual, (Jakarta: INIS, 1993), pp. 155-163. 
remarriage has become an arena where pelantar execute their influence too. As shown in the case of Kulsum, we see how cultural norms such as mompong, juddhu and apik are intertwined with religious rationales. Furthermore, Kulsum's out-of-court divorce suggests the importance of social acceptance than formal legal recognition. Her post-divorce life also has become an arena where pelantar extend their influence.

Another key actor of marriage is definitely kyai. Everyday practice of marriage in Pasuruan villages shows the on-going centrality of kyais roles in the production of an Islam-based legal norm to control sexual morality that sometimes confronts against the state legal norm. We see how different opinions within traditional figh doctrines have been essential for the construction of a legal reasoning that fits people's interest. The ability to exercise legal reasoning has turned into a fundamental means for a kyai to maintain his legitimate authority amidst the society. In addition, it is obvious that marriage has been, and is still, an effective way out to the problems of religious morality and woman sexuality.

Without a doubt, increasing participation in formal education and the rise of women's mobility have challenged this pattern. ${ }^{51}$ Formal schools provide a room where youth can meet prospect partners. Mutual love becomes more important. Because they have more rooms to exercise agency in the selection of a possible spouse, roles played by pelantar decrease. Nevertheless, finding a beloved partner for girls does not mean deciding when to marry. In many cases, the decision of marriage date belongs to the parents' authority. This is also related to the idea of preserving social honour of a family. []

\section{References}

\section{Book and Articles}

Alami, Dawoud Sudqi el-. The Marriage Contract in Islamic Law in the Shari ah and Personal Status Laws of Egypt and Morocco. London: Graham \& Trotman, 1992.

Ali, Kecia. "Marriage in Classical Islamic Jurisprudence: A Survey of Doctrines". Asifa Quraishi and Frank E. Vogel (eds). Islamic

51 Gavin Jones, "Which Indonesian Women Marry Youngest, and Why?," Journal of Southeast Asian Studies 32, 1 (2001): pp. 67-78. 
Marriage Contract: Case Studies in Islamic Family Law, 11-45. Cambridge, MA: Harvard Law School, Islamic Legal Studies Program, 2008.

al-San'ani, Muhammad ibn Ismail, Subul al-Salam, vol. 3, (Riyad: maktabah Nazar Mustafa al-Baz, 1995).

Badareen, Nayel. "Identity and Authority: Changes in the Process of Debates over the Islamic Marriage Contract among Contemporary Muslim-Arab Intellectuals". Ph.D Dissertation. The University of Arizona, 2014.

Beatty, Andrew. "Feeling Your Way in Java: An Essay on Society and Emotion". Ethnos: Journal of Anthropology 70, 1 (2005): 53-78.

Black, Ann, Hossein Esmaeili, and Nadirsyah Hosen. Modern Perspectives on Islamic Law. Cheltenham: Edward Elgar Publishing, 2013.

Bowen, John R. Islam, Law, and Equality in Indonesia: An Anthropology of Public Reasoning. Cambridge: Cambridge University Press, 2003. . Shari a, State, and Social Norms in France and Indonesia. ISIM Paper No. 3. Leiden: Institute for the Study of Islam in the Modern World, 2001.

Bruinessen, Martin van. "Kitab Kuning: Books in Arabic Script Used in the Pesantren Milieu, Comments on a New Collection in the KITLV Library." Bijdragen Tot de Taal-, Land-en Volkenkunde 146, 2 (1990): 226-269.

Cammack, Mark. “Islamic Law in Indonesia's New Order." International and Comparative Law Quarterly 38, 1 (1989): 53-73.

Cammack, Mark, Lawrence A. Young, and Tim B. Heaton. "Legislating Social Change in an Islamic Society: Indonesia's Marriage Law." The American Journal of Comparative Law 44, 1 (1996): 45-74.

Dhofier, Zamakhsyari. "Kinship and Marriage among the Javanese Kyai." Indonesia 29 (1980): 47-58.

- The Pesantren Tradition: The Role of the Kyai in the Maintenance of Traditional Islam in Java. Tempe: Arizona State University, 1999.

Fealy, Greg, and Robin Bush. "The Political Decline of Traditional Ulama in Indonesia." Asian Journal of Social Science 42, 5 (2014): 536-560. 
Geertz, Clifford. "Local Knowledge: Fact and Law in Comparative Perspective". Local Knowledge: Further Essays in Interpretive Anthropology. New York: Basic Books, 1983.

Geertz, Hildred. The Javanese Family: A Study of Kinship and Socialization. New York: The Free Press of Glencoe, 1961.

Gennep, Arnold van. The Rites of Passage. London: Routledge \& Kegan Paul, 1960.

Grijns, Mies, and Hoko Horii. "Child Marriage in a Village in West Java (Indonesia): Compromises between Legal Obligations and Religious Concerns." Asian Journal of Law and Society (2018): 114.

Hallaq, Wael B. Sharia: Theory, Practice, Transformations. Cambridge: Cambridge University Press, 2009.

Hoel, Nina, and Sa'diyya Shaikh. "Sex as Ibadah: Religion, Gender, and Subjectivity among South African Muslim Women". Journal of Feminist Studies in Religion 29, 1 (2013): 69-91.

Huis, Stijn van. "Islamic Courts and Women's Divorce Rights in Indonesia: The Cases of Cianjur and Bulukumba." Ph.D Dissertation. Leiden University, 2015.

Ibn Hajar al- 'Asqalānī, Ạ̣mad b. 'Alī. Bulügh Al-Marām Min Adillat AlAhkäm. Riyadh: Maktaba al-Rushd, 2005.

Ibn Mājah, Muḥammad ibn Yazīd. English Translation of Sunan Ibn Majah with Commentary. Vol. 3. Riyadh: Darussalam, 2007.

Idrus, Nurul Ilmi. Gender Relations in an Indonesian Society: Bugis Practices of Sexuality and Marriage. Leiden: Brill, 2016.

Jones, Gavin. "Which Indonesian Women Marry Youngest, and Why?". Journal of Southeast Asian Studies 32, 1 (2001): 67-78.

Koentjaraningrat. "Family and Religion in Indonesia." East Asian Cultural Studies 13, $1 / 4$ (1974): 59-68.

Mansurnoor, Iik Arifin. Islam in an Indonesian World: Ulama of Madura. Yogyakarta: Gadjah Mada University Press, 1990.

Mas'udi, Masdar F. "Perempuan Di Antara Lembaran Kitab Kuning." In Wanita Islam Indonesia Dalam Kajian Tekstual Dan Kontekstual, edited by Lies Marcoes and Johan Hendrik Meuleman, 155-163. Jakarta: INIS, 1993. 
Masud, Muhammad Khalid. "Gender Equality and the Doctrine of Wilāya." Ziba Mir-Hosseini, Kari Vogt, Lena Larsen, and Christian Moe (eds). Gender and Equality in Muslim Family Law: Justice and Ethics in the Islamic Legal Tradition, 127-152. London: I.B. Tauris, 2013.

Merry, Sally Engle. "Law, Culture, and Cultural Appropriation". Yale Journal of Law \& the Humanities 10, 2 (1998): 575-603.

Muhammad, Husein. Fiqh Perempuan: Refleksi Kiai Atas Wacana Agama Dan Gender. Yogyakarta: LKiS, 2001.

Niehof, Anke. Women and Fertility in Madura (Indonesia). Leiden: Instituut voor Culturele Antropologie en Sociologie der Niet-Westerse Volken, 1985.

Nilan, Pam. "Youth Transitions to Urban, Middle-Class Marriage in Indonesia: Faith, Family and Finances". Journal of Youth Studies 11, 1 (2008): 65-82.

O'Shaughnessy, Kate. Gender, State and Social Power in Contemporary Indonesia: Divorce and Marriage Law. London and New York: Routledge, 2009.

Platt, Maria. Marriage, Gender and Islam in Indonesia: Women Negotiating Informal Marriage, Divorce and Desire. Oxon and New York: Routledge, 2017.

Pranowo, M. Bambang. "Pesantren, Traditional Islam in Contemporary Rural Java: The Case of the Tegal Rejo Pesantren". M.C. Ricklefs (ed.). Islam in the Indonesian Social Context. Clayton: Monash University Centre of Southeast Asian Studies, 1991.

Pribadi, Yanwar. "Religious Networks in Madura: Pesantren, Nahdlatul Ulama, and Kiai as the Core of Santri Culture". Al-Jamiah: Journal of Islamic Studies 51, 1 (2013): 1-32.

Rozario, Santi. "Islamic Marriage: A Haven in an Uncertain World". Culture and Religion 13, (2015): 159-175.

—. "Islamic Piety against the Family: From 'traditional' to 'Pure' Islam". Contemporary Islam 5, 3 (2011): 285-308.

Salim, Arskal. Contemporary Islamic Law in Indonesia: Shariah and Legal Pluralism. Edinburgh: Edinburgh University Press, 2015. 
Sirry, Mun'im. "The Public Expression of Traditional Islam: The Pesantren and Civil Society in Post-Suharto Indonesia". The Muslim World 100, 1 (2010): 60-77.

Smith-Hefner, Nancy J. "The New Muslim Romance: Changing Patterns of Courtship and Marriage Among Educated Javanese Youth". Journal of Southeast Asian Studies 36, 3 (2005): 441-459.

Smith, Bianca J., and Mark Woodward. "Introduction, Decolonizing Islam and Muslim Feminism". Bianca J. Smith and Mark Woodward (eds). Gender and Power in Indonesian Islam: Leaders, Feminists, Sufis and Pesantren Selves. London and New York: Routledge, 2014.

Spectorsky, Susan A. Women in Classical Islamic Law: A Survey of the Sources. Leiden/Boston: Brill, 2010.

Srimulyani, Eka. Women from Traditional Islamic Educational Institutions in Indonesia: Negotiating Public Spaces. Amsterdam: Amsterdam University Press, 2012.

Tirmidhī, Ab̄̄ 'Īsā al-. Jāmi' Al-Tirmidhì. Riyadh: Bayt al-Afkār alDawliyya, 1999.

Wiyata, A. Latief. Carok: Konflik Kekerasan Dan Harga Diri Orang Madura. Yogyakarta: LKiS, 2002. 